Acta Agroph., 2018, 25(1), 45-58

doi: $10.31545 /$ aagr0004

\title{
THE EFFECT OF SOIL CONDITIONERS ON YIELD OF DRY MATTER, PROTEIN, AND SUGAR IN GRASS
}

\author{
Kazimierz Jankowski, Milena Truba, Beata Wiśniewska-Kadżajan, Jacek Sosnowski, \\ Elżbieta Malinowska \\ Faculty of Natural Sciences, Department of Grassland and Green Areas Creation \\ Siedlce University of Natural Sciences and Humanities \\ Prusa 14, 08-110 Siedlce, Poland \\ e-mail: milena.truba@uph.edu.pl
}

\begin{abstract}
A bstract. A three-year field experiment was set up in the experimental facility of the University of Natural Sciences and Humanities in Siedlce $\left(52^{\circ} 12^{\prime} \mathrm{N}, 22^{\circ} 28^{\prime} \mathrm{E}\right)$ in the autumn of 2011 . It was carried out in a split-plot design, in three replicates, with plots of $3 \mathrm{~m}^{2}$ as experimental units. The purpose of the research was to examine whether soil conditioners (UGmax, Eko-Użyźniacz, Humus Active Papka) available on the market and used in farming substantially increase the yield of dry matter, together with total protein and soluble carbohydrate content, in selected grass species (Dactylis glomerata L., Lolium perenne L.). Out of all treatments, UGmax with mineral fertilisation increased the yield of dry matter, total protein, and soluble carbohydrates to the highest level. The soil conditioners applied in the experiment positively affected the content of nutrients, which could have contributed to an increase in forage intake by animals. These results confirm the advantages of their use in organic farming, creating the possibility of a partial reduction of mineral fertilisers use.

Ke yw ord s: biological preparations, dry matter yield, protein yield, sugar yield, grass, Dactylis Glomerata L., Lolium perenne L.
\end{abstract}

\section{INTRODUCTION}

Grass is one of the most important crops in many parts of the world, with its cell wall components making it essential animal feedstuff (Vogel 2008). What decides about good nutritional value of grass and affects its palatability is large protein and simple sugar content with relatively low amounts of crude fibre and its fractions (Bertilsson et al. 2017). Apart from roughage such as grass, farmers also use supplements to provide animals with optimal amounts of protein. However, they are usually more expensive than good forage containing similar amounts of nutrients (Elsaesser et al. 2014, Huhtanen and Broderick 2016). Literature reports indicate 
that forage yield, and at the same time protein yield, per hectare is variable, not always high, which may have a significant impact on the performance of grass-based dairy farms. Therefore, the question of increasing the amount of protein produced per hectare is an important issue for such farms, raised in numerous publications (Peyraud et al. 2014, Peyraud and Peeters 2016, Johansen et al. 2016).

Soluble sugars not only improve grass taste, increasing forage consumption by animals, but their high concentration in the tissues of leaves and stalks results in better digestion of protein and, consequently, positively affects meat and milk production (Wilkins and Humphreys 2003). According to literature (Robins et al. 2016, Sanada et al. 2010), soluble carbohydrates, along with improving forage quality, increase resistance to abiotic stress.

The way how animals are fed, whether in the production process compound feed has been used or only natural forage, is of growing interest among people consuming animal products. In organic farming the use of mineral fertiliser is unacceptable and therefore this type of farms highly depend on ecosystem processes that occur spontaneously (Brossaard et al. 2007). To support those processes many products called soil conditioners, the composition of which is based on useful micro-organisms, seaweed extracts, and humus, have been authorised for use in organic agriculture (Daly and Stewart 1999, Szczepanek and Wilczewski 2011, Sosnowski 2012). The purpose of the research was to examine whether soil conditioners available on the market and used in farming substantially increase the yield of dry matter, together with total protein, and soluble carbohydrate content in selected grass species.

\section{MATERIAL AND METHODS}

\section{Experiment location}

The three-year field experiment was set up in the experimental facility of the University of Natural Sciences and Humanities in Siedlce $\left(52^{\circ} 12^{\prime} \mathrm{N}, 22^{\circ} 28^{\prime} \mathrm{E}\right)$ in the autumn of 2011. It was carried out in a split-plot design, in three replicates, with plots of $3 \mathrm{~m}^{2}$ as experimental units. The soil of the plots had granulometric composition of loamy sand, belonging to the order of anthrosol, the type of culture earth, and the subtype of hortisols (Polish Soil Classification 2011).

Chemical analysis of the soil showed that organic carbon content $\left(\mathrm{C}_{\text {org }}\right)$ was $13.50 \mathrm{~g} \mathrm{~kg}^{-1} \mathrm{DM}$, with total nitrogen content of $1.30 \mathrm{~g} \mathrm{~kg}^{-1} \mathrm{DM}$. The ratio of carbon in organic compounds to total nitrogen $(\mathrm{C}: \mathrm{N})$ in the soil was $10.3: 1$, and $\mathrm{pH}$ was 6.8. The concentration of total forms of other macronutrients was high $\left(\mathrm{g} \mathrm{kg}^{-1}\right.$ $\mathrm{DM}$ ): $\mathrm{P}-0.75 ; \mathrm{K}-1.12 ; \mathrm{Ca}-1.80 ; \mathrm{Mg}-1.20 ; \mathrm{Na}-0.15$, and the concentration of micronutrients was the following $\left(\mathrm{mg} \mathrm{kg}^{-1} \mathrm{DM}\right)$ : $\mathrm{Fe}-4562.80 ; \mathrm{Mn}-156.20$; $\mathrm{Cu}-5.60 ; \mathrm{Zn}-14.50$. 


\section{Experimental factors}

The main factors in the experiment were soil conditioners with the trade names of UGmax, Eko-Użyźniacz, and Humus Active Papka, applied separately and supplemented with NPK fertilisers. These conditioners were tested on two species of fodder grass - Dactylis glomerata L. var. Bora and Lolium perenne L. var. Info.

According to the Institute of Soil Science and Plant Cultivation in Puławy, soil conditioners improve soil properties. They were used annually in the spring before the growing season in the following doses: UGmax $-0.61 \mathrm{ha}^{-1}$, Eko-Użyźniacz - $151 \mathrm{ha}^{-1}$, Humus Active Papka - $501 \mathrm{ha}^{-1}$. The UGmax soil conditioner is an extract from compost, containing macronutrients $(\mathrm{N}, \mathrm{P}, \mathrm{K}, \mathrm{Mg}, \mathrm{Na})$ and micronutrients (Mn). It also contains lactic acid bacteria, photosynthetic bacteria, Azotobacter, Pseudomonas, yeast, and Actinomycetes (Tab. 1). The microorganisms in the conditioner have a capacity of processing organic and natural fertilisers into compost and humus. These processes are conducive not only to the production of humus but also to improving soil structure, which in turn has a positive effect on water balance in the soil. In addition, the UGmax soil conditioner increases disease resistance, keeping plants healthy, but it also stimulates the development of the root system and supports the biological reduction of molecular nitrogen.

Table 1. Ingredients of the soil conditioners

\begin{tabular}{|c|c|c|c|c|c|c|c|c|c|c|c|c|}
\hline \multirow[t]{2}{*}{ Soil conditioner } & \multicolumn{6}{|c|}{$\begin{array}{l}\text { Macronutrients } \\
\left(\mathrm{g} \mathrm{kg}^{-1}\right)\end{array}$} & \multicolumn{5}{|c|}{$\begin{array}{c}\text { Micronutrients } \\
\left(\mathrm{mg} \mathrm{kg}^{-1}\right)\end{array}$} & \multirow[t]{2}{*}{ Microorganisms and others } \\
\hline & $\mathrm{N}$ & $\mathrm{P}$ & $\mathrm{K}$ & $\mathrm{Ca}$ & $\mathrm{Mg}$ & $\mathrm{Na}$ & $\mathrm{Mn}$ & $\mathrm{Fe}$ & $\mathrm{Zn}$ & $\mathrm{Cu}$ & Mo & \\
\hline $\begin{array}{l}\text { Humus } \\
\text { Active Papka } \\
\text { (HA) }\end{array}$ & 0.2 & 1.3 & 4.6 & 3.0 & 0.5 & - & 15 & 500 & 3 & 1 & - & $\begin{array}{l}\text { Active humus with useful } \\
\text { microorganisms }\end{array}$ \\
\hline $\begin{array}{l}\text { Eko-Użyźniacz } \\
\text { (EU) }\end{array}$ & 0.6 & 0.3 & 0.7 & - & - & - & - & - & - & - & - & $\begin{array}{c}\text { Endo micorrhiza, fungi, bacteria, } \\
\text { enzymes of earthworms } \\
\text { lactic acid bacteria, }\end{array}$ \\
\hline $\begin{array}{l}\text { UGmax } \\
\text { (UG) }\end{array}$ & 1.2 & 0.2 & 2.9 & - & 0.1 & 0.2 & 0.3 & - & - & - & - & $\begin{array}{c}\text { photosynthetic bacteria, } \\
\text { Azotobacter, Pseudomonas, } \\
\text { yeast, Actinomycetes }\end{array}$ \\
\hline
\end{tabular}

Humus Active Papka contains macronutrients ( $, \mathrm{P}, \mathrm{K}, \mathrm{Ca}, \mathrm{Mg}$ ), trace elements (Mn, Fe, $\mathrm{Zn}, \mathrm{Cu}$ ), and active humus with useful microorganisms (Tab. 1). According to the manufacturer, Humus Active Papka, among other beneficial effects, positively affects plant health as well as soil structure, and releases nutrients not readily available to plants.

Eko-Użyźniacz is extracted from bovine vermicompost and contains the main macronutrients $(\mathrm{N}, \mathrm{P}, \mathrm{K})$, microorganisms, and enzymes related to the metabolism of earthworms (Tab. 1). This soil conditioner stimulates biological life in soil degraded chemically, mechanically or biologically, and increases plant resistance to different stress factors. 
Mineral nitrogen, phosphorus and potassium (NPK) fertilisers were used in the following doses: $\mathrm{N}-150, \mathrm{P}\left(\mathrm{P}_{2} \mathrm{O}_{5}\right)-80, \mathrm{~K}\left(\mathrm{~K}_{2} \mathrm{O}\right)-120 \mathrm{~kg} \mathrm{ha}^{-1}$. Mineral nitrogen was applied in the form of ammonium nitrate $\left(\mathrm{NH}_{4} \mathrm{NO}_{3}\right)$, phosphorous in the form of triple superphosphate granulated $\left(\mathrm{Ca}\left(\mathrm{H}_{2} \mathrm{PO}_{4}\right)_{2}\right)$, and potassium in the form of high percentage potassium chloride $(\mathrm{KCl})$. Phosphorus fertilisation was applied once in the spring, while nitrogen and potassium doses were split into three equal parts: first before the growing season, second and third after the first and second harvest.

\section{Weather conditions}

In order to determine temporal variation of meteorological elements and their effects on vegetation, the Sielianinov hydrothermal coefficient was calculated on the basis of monthly sums of precipitation and monthly sum of air temperature (Skowera and Puła 2004). The values of Sielianinov hydrothermal coefficient for individual months in the experimental period are shown in Table 2. In the first year (2012), optimal temperature and precipitation were noted only in June and October. In the remaining months of that growing season the conditions were dry or extremely dry. In the following years, dry periods were followed by wet ones, with the best conditions only in April 2013, April 2014, and in July 2013.

Table 2. Sielianinov hydrothermal coefficient $(\mathrm{K})$ values during the growing seasons

\begin{tabular}{cccccccc}
\hline \multirow{2}{*}{ Year } & \multicolumn{7}{c}{ Months } \\
\cline { 2 - 7 } & IV & V & VI & VII & VIII & IX & X \\
\hline 2012 & $1.12(\mathrm{md})$ & $1.22(\mathrm{md})$ & $1.56(\mathrm{o})$ & $0.69(\mathrm{std})$ & $0.94(\mathrm{~d})$ & $0.27(\mathrm{sd})$ & $1.32(\mathrm{o})$ \\
2013 & $1.60(\mathrm{o})$ & $2.20(\mathrm{w})$ & $1.80(\mathrm{mw})$ & $1.50(\mathrm{o})$ & $0.25(\mathrm{sd})$ & $2.70(\mathrm{vw})$ & $1.22(\mathrm{md})$ \\
2014 & $1.53(\mathrm{o})$ & $2.29(\mathrm{w})$ & $1.20(\mathrm{md})$ & $0.16(\mathrm{sd})$ & $1.95(\mathrm{mw})$ & $0.59(\mathrm{std})$ & $0.13(\mathrm{sd})$ \\
\hline
\end{tabular}

$\mathrm{sd}$ - severe drought; std - strong drought; $\mathrm{d}$ - drought; $\mathrm{md}$ - moderate drought; o - optimal; mw moderately wet period; $\mathrm{w}$ - wet period; $\mathrm{vw}$ - very wet period

The best hydrothermal conditions occurred in the first half of the growing period, regardless of the year of the experiment. Throughout the experiment, during one third of the growing seasons there were extreme weather conditions, mainly from July to September, ranging from severe or strong drought to wet and very wet periods.

\section{Analysis}

Dry matter yield was determined with the drying and weighing method. Content of protein and simple sugars in plant material was measured with near-infrared spectroscopy using the LSDFlex N-500 spectrometer, with the INGOT calibration package for dry feed. Based on the dry matter concentration of protein and sugars, protein and soluble carbohydrate yields were calculated. 


\section{Statistical analyses}

The results of the research were processed statistically using three-factor analysis of variance. Verification of the significance of the impact of experimental factors on tested characteristics was done with the Fisher-Snedecor test, and Tukey's test was used to evaluate differences between means. The calculations were done with the Statistica 13 Program.

\section{RESULTS}

\section{Dry matter yield of Dactylis glomerata $\mathbf{L}$. and Lolium perenne $\mathbf{L}$.}

The largest increase in the annual yield of dry matter (Tab. 3), 55 to $69 \%$ higher than in the control plot, was recorded after the application of soil conditioners along with mineral fertilisation. A significant increase in annual dry matter yield was also noted after the application of mineral fertilisers and soil conditioners separately (from 31 to 33\%), with the exception of the plot treated with Humus Active Papka.

Table 3. The effect of fertiliser treatments on annual yield of dry matter of investigated grass species $\left(\mathrm{Mg} \mathrm{ha}^{-1}\right)$

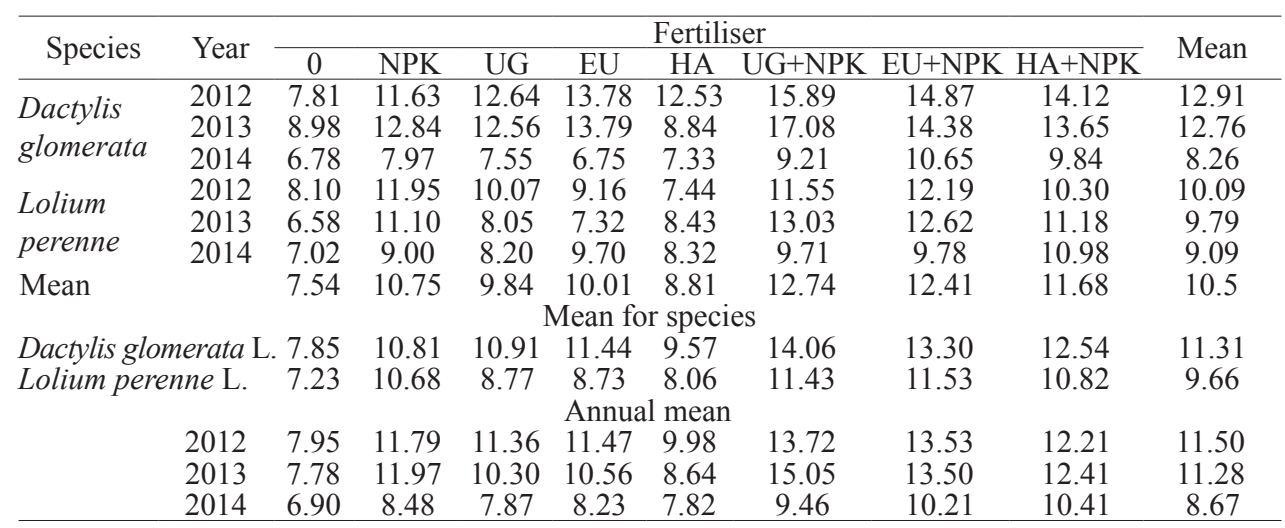

$\mathrm{LSD}_{0.05}$ for: Fertiliser $=2.30 ;$ Species $=1.65 ;$ Year $=2.61 ;$ Fertiliser $/$ Species $=3.24 ;$ Fertiliser $/$ Year $=3.51$; Species $/$ Year $=1.83 ;$ Fertiliser $/$ Species $/$ Year $=1.18$

The analysis of the results showed that the annual yield of dry matter of Dactylis glomerata L. (11.31 $\mathrm{Mg} \mathrm{ha}^{-1}$ ) was significantly higher, by $17 \%$, than the annual yield of Lolium perenne L. dry matter $\left(9.66 \mathrm{Mg} \mathrm{ha}^{-1}\right)$. For both species of grass the largest increase of yield was noted after the application of UGmax together with NPK and Eko-Użyźniacz together with NPK fertilisation; in the case of Dactylis glomerata $\mathrm{L}$. the yield was, respectively, $14.06 \mathrm{Mg} \mathrm{ha}^{-1}$ and $13.30 \mathrm{Mg} \mathrm{ha}^{-1}$, which means an increase from 69 to $79 \%$ relative to the control. For Lolium perenne L. it 
was $11.43 \mathrm{Mg} \mathrm{ha}^{-1}$ on the plot where UGmax was applied together with NPK, and $11.53 \mathrm{Mg} \mathrm{ha}^{-1}$ on the plot where Eko-Użyźniacz was used also with NPK fertilisers. The increase relative to the control plot for this species was about $59 \%$.

The annual yield of dry matter of Dactylis glomerata L. in the first year of the experiment $\left(12.91 \mathrm{Mg} \mathrm{ha}^{-1}\right)$ and in the second $\left(12.76 \mathrm{Mg} \mathrm{ha}^{-1}\right)$ was significantly greater than in the third year $\left(8.26 \mathrm{Mg} \mathrm{ha}^{-1}\right)$. In turn, in the case of Lolium perenne L. yield, there were no significant differences throughout the experiment. By analysing various years, taking into account the average of both species growing on plots with different fertiliser treatments, it was found that the annual dry matter yield in the first year $\left(11.50 \mathrm{Mg} \mathrm{ha}^{-1}\right)$ and second year $\left(11.28 \mathrm{Mg} \mathrm{ha}^{-1}\right)$ was significantly greater than in the third year $\left(8.67 \mathrm{Mg} \mathrm{ha}^{-1}\right)$.

In regard to the yield of dry matter in all harvests (Tab. 4) it was found that the first (3.72 $\left.\mathrm{Mg} \mathrm{ha}^{-1}\right)$ and second harvest $\left(3.61 \mathrm{Mg} \mathrm{ha}^{-1}\right.$ ) were significantly larger than the third one $\left(3.15 \mathrm{Mg} \mathrm{ha}^{-1}\right)$. Considering the harvests of both grass species throughout the growing periods, it was found that in the case of Dactylis glomerata L. the dry matter yield in the first harvest $\left(4.05 \mathrm{Mg} \mathrm{ha}^{-1}\right)$ and in the second $\left(3.92 \mathrm{Mg} \mathrm{ha}^{-1}\right)$ was significantly greater than in the third $\left(3.34 \mathrm{Mg} \mathrm{ha}^{-1}\right)$. In turn, dry matter yield of Lolium perenne L. did not differ significantly between harvests.

Table 4. The effect of fertiliser treatments on individual harvest yields of dry matter of investigated grass species $\left(\mathrm{Mg} \mathrm{ha}^{-1}\right)$

\begin{tabular}{lcccccccccc}
\hline \multirow{2}{*}{ Species } & Cut & \multicolumn{10}{c}{ Fertiliser } & \multirow{10}{*}{ Mean } \\
\cline { 3 - 9 } Dactylis & I & 2.90 & 3.87 & UG & EU & HA & UG+NPK & EU+NPK & HA+NPK & \\
glomerata & II & 2.77 & 3.74 & 3.79 & 3.12 & 3.40 & 5.06 & 4.74 & 4.40 & 4.05 \\
Lolium & III & 2.18 & 3.20 & 3.23 & 3.43 & 2.82 & 4.92 & 4.64 & 4.30 & 3.92 \\
perenne & II & 2.61 & 3.75 & 3.07 & 3.07 & 2.93 & 4.04 & 3.93 & 3.84 & 3.34 \\
& III & 2.49 & 3.65 & 3.01 & 3.98 & 2.77 & 3.87 & 3.88 & 3.76 & 3.40 \\
& 2.14 & 3.28 & 2.69 & 2.68 & 2.37 & 3.52 & 3.65 & 3.39 & 2.96 \\
& I & 2.75 & 3.81 & 3.48 & 3.59 & 3.16 & 4.55 & 4.37 & 4.08 & 3.72 \\
& II & 2.63 & 3.70 & 3.40 & 3.44 & 3.06 & 4.39 & 4.26 & 3.98 & 3.61 \\
& III & 2.16 & 3.24 & 2.96 & 3.05 & 2.59 & 3.80 & 3.79 & 3.62 & 3.15 \\
\hline
\end{tabular}

$\mathrm{LSD}_{0.05}$ for: $\mathrm{Cut}=0.45 ;$ Fertiliser $/ \mathrm{Cut}=0.89 ;$ Species $/ \mathrm{Cut}=0.44 ;$ Fertiliser $/$ Species $/ \mathrm{Cut}=1.25$

Protein yield in dry matter of Dactylis glomerata L. and Lolium perenne L.

Mineral fertilisation combined with soil conditioners resulted in a significant increase of total protein yield which was about $75 \%$ higher relative to the control after the application of Humus Active Papka, and about $89 \%$ higher on the plots with UGmax and Eko-Użyźniacz (Tab. 5). Additionally, a significant increase in the yield of protein was reported on plots where mineral fertilisation $\left(1532.5 \mathrm{~kg} \mathrm{ha}^{-1}\right)$ and Eko-Użyźniacz (1430.7 $\mathrm{kg} \mathrm{ha}^{-1}$ ) were applied separately. 
Total protein yield in dry matter of Dactylis glomerata L. was significantly higher $\left(1653.8 \mathrm{~kg} \mathrm{ha}^{-1}\right)$ than in dry matter yield of Lolium perenne L. $\left(1433.2 \mathrm{~kg} \mathrm{ha}^{-1}\right)$. The annual yield of total protein in dry matter was significantly higher in the first year of the experiment $\left(1651.8 \mathrm{~kg} \mathrm{ha}^{-1}\right)$ and the second one $\left(1703.8 \mathrm{~kg} \mathrm{ha}^{-1}\right)$ than in the last year $\left(1275.0 \mathrm{~kg} \mathrm{ha}^{-1}\right)$.

For both grass species the largest yield of total protein was obtained on the plots where soil conditioners were applied together with mineral fertilisation. The increase in the yield of this nutrient ranged from 81 to $100 \%$ for Dactylis glomera$t a \mathrm{~L}$. and from 68 to $88 \%$ for Lolium perenne L. In the first year of the experiment (2012), the use of the same soil conditioners, i.e. UGmax, Eko-Użyźniacz, and Humus Active Papka, also resulted in an increased yield of protein (from 40 to $50 \%$ higher than the control - Tab. 5). In the second year (2013) this treatment also resulted in a significant increase in the yield of protein after the application of UGmax, at $1685.6 \mathrm{~kg} \mathrm{ha}^{-1}$, and Eko-Użyźniacz, $1845.4 \mathrm{~kg} \mathrm{ha}^{-1}$. For the species Lolium perenne L. a significant increase, by about $20 \%$, in the yield of its total protein was noted in the second year (2013) after the application of Humus Active Papka.

Total protein yield of Lolium perenne L. did not differ significantly in the years of the research. Dactylis glomerata L. produced equal yields in the first two years of the study (Tab. 5). A significant decline in the yield of protein - approximately $46 \%$ - occurred in the third year of the research (2014) and was $1265.3 \mathrm{~kg} \mathrm{ha}^{-1}$.

Table 5. The effect of fertiliser treatments on annual yield of protein of investigated grass species $\left(\mathrm{kg} \mathrm{ha}^{-1}\right)$

\begin{tabular}{|c|c|c|c|c|c|c|c|c|c|c|}
\hline \multirow{2}{*}{ Species } & \multirow{2}{*}{ Year } & \multicolumn{8}{|c|}{ Fertiliser } & \multirow[b]{2}{*}{ Mean } \\
\hline & & 0 & NPK & UG & EU & HA & UG+NPK & EU+NPK & $\mathrm{HA}+\mathrm{NPK}$ & \\
\hline \multirow{3}{*}{$\begin{array}{l}\text { Dactylis } \\
\text { glomerata }\end{array}$} & 2012 & 945.6 & 1632.9 & 1553.1 & 1895.0 & 1845.4 & 2509.0 & 2200.9 & 2208.4 & 1848.8 \\
\hline & 2013 & 1290.4 & 1813.8 & 1685.6 & 1845.4 & 1217.9 & 2535.5 & 2209.3 & 2180.4 & 1847.3 \\
\hline & 2014 & 1010.9 & 1130.7 & 1088.6 & 1052.7 & 1168.3 & 1464.8 & 1721.4 & 1484.8 & 1265.3 \\
\hline \multirow{3}{*}{$\begin{array}{l}\text { Lolium } \\
\text { perenne }\end{array}$} & 2012 & 1021.8 & 1699.6 & 1099.9 & 1262.2 & 987.2 & 1774.5 & 2131.0 & 1661.8 & 1454.8 \\
\hline & 2013 & 927.1 & 1770.0 & 1126.4 & 1182.6 & 1397.2 & 1976.4 & 2247.1 & 185 & 1560.3 \\
\hline & 2014 & 1087.1 & 1148.3 & 939.7 & 1346.6 & 1210.2 & 1637.5 & 1322.2 & 1585.8 & 1284.7 \\
\hline \multicolumn{2}{|l|}{ Mean } & 1047.1 & 1532.5 & $\begin{array}{r}1248.9 \\
\mathrm{Me}\end{array}$ & $\begin{array}{l}1430.7 \\
\text { ean for } s\end{array}$ & $\begin{array}{l}1304.4 \\
\text { pecies }\end{array}$ & 1983.0 & 1972.0 & 1829.5 & 1543.5 \\
\hline \multirow{2}{*}{\multicolumn{2}{|c|}{$\begin{array}{l}\text { Dactylis } \\
\text { glomerata } \mathrm{L} . \\
\text { Lolium perenn }\end{array}$}} & 1082.3 & 1525.8 & 1442.4 & 1597.7 & 1410.6 & 2169.9 & 2043.8 & 1957.9 & 1653.8 \\
\hline & & 1012.0 & 1539.3 & $\begin{array}{r}1055.3 \\
\text { A }\end{array}$ & $\begin{array}{l}1263.8 \\
\text { Annual } \mathrm{n}\end{array}$ & $\begin{array}{l}1198.2 \\
\text { nean }\end{array}$ & 1796.1 & 1900.1 & 1701.1 & 1433.2 \\
\hline & 2012 & 983.0 & 1666.2 & 1326.5 & 1578.6 & 1416.3 & 2141.7 & 2165.9 & 1935.1 & 1651.8 \\
\hline & & 1108.7 & & 1406.0 & 1514.0 & 1307.6 & 2255.9 & & & 1703.8 \\
\hline & 2014 & 1049.0 & 1139.5 & 1014.2 & 1199.6 & 1189.3 & 1551.2 & 1521.8 & 1535.3 & 1275.0 \\
\hline
\end{tabular}

$\mathrm{LSD}_{0.05}$ for: Fertiliser $=383.6$; Species $=220.6$; Year $=376.8 ;$ Fertiliser $/$ Species $=470.5 ;$ Fertiliser Year $=499.7 ;$ Species $/$ Year $=392.5 ;$ Fertiliser $/$ Species $/$ Year $=227.2$

No significant differences were found between the yields of total protein in individual harvests (Tab. 6). Comparing the yields or total protein in dry matter of both species of grass, it was noted that in the first and the second harvest the yield 
of Dactylis glomerata L. was significantly greater than the yield of Lolium perenne L. In the third harvest there were no significant differences in the yield of total protein between the two grass species.

Table 6. The effect of fertiliser treatments on individual harvest yield of total protein of investigated grass species $\left(\mathrm{kg} \mathrm{ha}^{-1}\right)$

\begin{tabular}{lcccccccccc}
\hline \multirow{2}{*}{ Species } & \multirow{2}{*}{ Cut } & \multicolumn{10}{c}{ C } & NPK & UG & EU & HA & UG+NPK & EU+NPK HA+NPK & \multirow{2}{*}{ Mean } \\
\hline Dactylis & I & 370.7 & 480.3 & 441.6 & 581.1 & 442.1 & 716.7 & 725.9 & 581.9 & 542.6 \\
glomerata L. & II & 366.5 & 523.6 & 538.3 & 537.5 & 522.6 & 794.6 & 698.8 & 716.2 & 587.3 \\
III & 335.7 & 512.3 & 453.9 & 478.3 & 435.7 & 645.8 & 610.1 & 648.7 & 515.1 \\
Lolium & I & 337.4 & 489.0 & 331.9 & 379.5 & 419.1 & 584.4 & 578.9 & 602.6 & 464.2 \\
& II & 313.0 & 468.1 & 347.0 & 420.8 & 389.0 & 585.2 & 677.9 & 514.7 & 464.5 \\
& III & 351.0 & 579.0 & 370.1 & 453.2 & 382.0 & 619.0 & 639.6 & 580.0 & 496.7 \\
& I & 354.1 & 480.1 & 386.7 & 480.3 & 430.6 & 650.6 & 652.4 & 592.3 & 503.4 \\
& II & 339.8 & 495.8 & 442.6 & 479.2 & 455.8 & 689.9 & 688.3 & 615.5 & 525.9 \\
& III & 343.4 & 545.7 & 412.0 & 465.7 & 408.9 & 632.4 & 624.8 & 614.3 & 505.9 \\
\hline
\end{tabular}

$\mathrm{LSD}_{0.05}$ for: $\mathrm{Cut}=$ insignificant; Fertiliser $/ \mathrm{Cut}=152.3 ;$ Species $/ \mathrm{Cut}=78.1 ;$ Fertiliser $/$ Species $/ \mathrm{Cut}=214.3$

Soluble sugar yield in dry matter of Dactylis glomerata L. and Lolium perenne L.

The yield of soluble sugars (Tab. 7) in the grass was the largest on the plot where UGmax was applied in combination with mineral fertilisation $\left(754.1 \mathrm{~kg} \mathrm{ha}^{-1}\right)$. The yields from the other plots did not differ significantly from that on the control plot (491.0 $\mathrm{kg} \mathrm{ha}^{-1}$ ). The yield of Lolium perenne L. soluble carbohydrates was $21 \%$ higher than in the case of Dactylis glomerata L.

Table 7. The effect of fertiliser treatments on annual soluble carbohydrate yield of investigated grass species $\left(\mathrm{kg} \mathrm{ha}^{-1}\right)$

\begin{tabular}{|c|c|c|c|c|c|c|c|c|c|c|}
\hline \multirow{2}{*}{ Species } & \multirow{2}{*}{ Year } & \multicolumn{8}{|c|}{ Fertiliser } & \multirow{2}{*}{ Mean } \\
\hline & & 0 & NPK & UG & EU & HA & UG+NPK & EU+NPK & $\mathrm{HA}+\mathrm{NPK}$ & \\
\hline Dactvlis & 2012 & 480.9 & 550.2 & 672.0 & 572.6 & 578.8 & 773.8 & 531.7 & 604.3 & 595.5 \\
\hline & 2013 & 393.0 & 482.4 & 629.5 & 627.6 & 376.0 & 896.3 & 531.1 & 515.9 & 556.5 \\
\hline omerata & 2014 & 301.2 & 351.4 & 351.3 & 348.4 & 347.3 & 430.3 & 533.6 & 574.8 & 404.8 \\
\hline Lolium & 2012 & 711.6 & 705.2 & 709.2 & 651.7 & 550.2 & 1022.1 & 724.2 & 739.7 & 726.7 \\
\hline & 2013 & 583.0 & 740.3 & 555.5 & 483.8 & 528.7 & 879.2 & 681.6 & 602.0 & 631.8 \\
\hline perenne & 2014 & 476.4 & 581.3 & 543.0 & 537.0 & 494.2 & 522.9 & 462.8 & 604.8 & 527.8 \\
\hline \multicolumn{2}{|c|}{ Mean } & 491.0 & 568.5 & \multirow{2}{*}{\multicolumn{5}{|c|}{ Mean for species }} & 606.9 & 573.9 \\
\hline Dactylis glor & erata L. & 391.7 & 461.3 & 550.9 & 516.2 & 434.1 & & & & 518.9 \\
\hline Lolium pere & ne L. & 590.3 & 675.6 & 602.6 & 557.5 & 524.3 & 808.1 & 622.9 & 6489 & 628.8 \\
\hline \multicolumn{11}{|c|}{ Annual mean } \\
\hline & 2012 & 596.3 & 627.7 & 690.6 & 612.1 & 564.5 & 897.9 & 628.0 & 672.0 & 661.1 \\
\hline & 2013 & 488.0 & 611.3 & 592.5 & 555.7 & 452.3 & 887.8 & 606.3 & 558.9 & 594.1 \\
\hline & 2014 & 388.8 & 466.3 & 447.2 & 442.7 & 420.8 & 476.6 & 498.2 & 589.8 & 466.3 \\
\hline
\end{tabular}

$\mathrm{LSD}_{0.05}$ for: Fertiliser $=147.2 ;$ Species $=109.9 ;$ Year $=127.8 ;$ Fertiliser $/$ Species $=187.5 ;$ Fertiliser $/$ Year $=190.6 ;$ Species $/$ Year $=94.9 ;$ Fertiliser $/$ Species $/$ Year $=83.35$ 
By analysing soluble carbohydrate production by plants in the years of the experiment it was found that the yield in the first year $\left(661.1 \mathrm{~kg} \mathrm{ha}^{-1}\right)$ and in the second $\left(594.1 \mathrm{~kg} \mathrm{ha}^{-1}\right)$ was higher than in the last year of the experiment $\left(466.3 \mathrm{~kg} \mathrm{ha}^{-1}\right)$. The low yield of sugars in the last year of the study was caused by the low dry matter yield of both grass species.

In the case of Lolium perenne L., soluble carbohydrate yield decreased considerably, by $15-20 \%$ (Tab. 7), in the successive years of the experiment. In Dactylis glomerata $\mathrm{L}$. it was at a similar level in the first and the second years, but in the third year this yield significantly decreased, by $37 \%$.

It was noted that during the experiment soluble sugar yield, as an average for both grass species and all fertiliser treatments, was significantly greater in the first harvest $\left(271.8 \mathrm{~kg} \mathrm{ha}^{-1}\right)$ than in the second $\left(192.3 \mathrm{~kg} \mathrm{ha}^{-1}\right)$ or the third $\left(119.3 \mathrm{~kg} \mathrm{ha}^{-1}\right)$. The difference between the above cuts was from 29 to $56 \%$.

Table 8. The effect of fertiliser treatments on soluble carbohydrate yield in individual harvests of investigated grass species $\left(\mathrm{kg} \mathrm{ha}^{-1}\right)$

\begin{tabular}{lcrrrrrrrrr}
\hline \multirow{2}{*}{ Species } & \multirow{2}{*}{ Cut } & \multicolumn{10}{c}{ O } & \multicolumn{1}{c}{ NPK } & UG & EU & HA & UG+NPK & EU+NPK & HA+NPK & Mean \\
\hline Dactylis & I & 177.3 & 216.6 & 260.8 & 262.8 & 211.2 & 330.0 & 283.0 & 277.7 & 252.4 \\
glomerata & II & 134.5 & 158.2 & 180.9 & 170.9 & 138.2 & 257.8 & 171.3 & 182.8 & 174.3 \\
Lolium & III & 87.4 & 95.2 & 118.2 & 95.6 & 91.5 & 129.9 & 91.7 & 113.2 & 102.8 \\
perenne & I & 299.3 & 307.7 & 264.4 & 233.3 & 251.9 & 391.8 & 277.6 & 302.7 & 291.1 \\
& III & 180.0 & 212.0 & 209.7 & 201.8 & 176.3 & 279.1 & 209.4 & 214.1 & 210.3 \\
& 122.8 & 162.0 & 135.0 & 128.5 & 107.8 & 150.9 & 140.9 & 139.0 & 135.9 \\
& I & 238.3 & 262.2 & 262.6 & 248.0 & 321.5 & 360.9 & 280.3 & 290.2 & 271.8 \\
& II & 157.3 & 185.1 & 195.3 & 186.3 & 157.3 & 268.5 & 190.4 & 198.5 & 192.3 \\
& III & 105.1 & 128.6 & 126.6 & 112.1 & 99.6 & 140.4 & 116.3 & 126.1 & 119.3 \\
\hline
\end{tabular}

$\mathrm{LSD}_{0.05}$ for: $\mathrm{Cut}=79.5 ;$ Fertiliser $/ \mathrm{Cut}=62.9 ;$ Species $/ \mathrm{Cut}=33.1 ;$ Fertiliser $/$ Species $/ \mathrm{Cut}=87.0$

\section{DISCUSSION}

Biomass yield is a very important parameter in assessing the suitability of grass species for fodder. Both of the grass species used in the experiment are considered to be valuable forage crops, but the performance of each of them as grassland plants is different (Billman et al. 2017, Hammond et al. 2011). As Robins et al. (2016) pointed out, Dactylis glomerata L. is a grass producing high amounts of dry matter, compared with other species of fodder grass. Comparing the average yield of all harvests and all plots it was found that the first harvest of Dactylis glomerata L. was the largest, while the remaining ones varied depending on weather conditions. Butkute et al. (2014) found similar tendencies in their experiment.

Both grass species reacted with the largest increase in dry matter yield after the application of UGmax and Eko-Użyźniacz together with NPK fertiliser. These results were in line with the findings of Sosnowski (2012) who, in his experiment 
with Lolium perenne L., Dactylis glomerata L. and Festuca pratensis also found that the largest increase in the annual yield of dry matter was obtained after applying UGmax together with mineral fertilisation. According to Tarakanovas and Chomiak (2008), Dactylis glomerata L. is a species that produces the highest yield in the third and fourth year after sowing. However, in the present experiment the low yield in the last third year (2014) of the experiment might have been due to adverse weather conditions having an impact on the growth of plants, when a shortage of rainfall during the growing period was followed by its excess, slowing down the development of this grass species. In turn, in the case of Lolium perenne L. there were no significant differences between the average annual dry matter production, indicating that this species is less sensitive to dynamic weather conditions (Foito et al. 2009).

Mineral fertilisation, when combined with Humus Active Papka, resulted in a significant increase, of $75 \%$, in the yield of total protein compared to the control, and in about an $89 \%$ increase when it was used together with UGmax and Eko-Użyźniacz. According to Tas et al. (2006), an increase in protein content in the yield depends on the amount of nitrogen supplied to plants. In the case of EkoUżyźniacz, this soil conditioner contains low amounts of nitrogen $\left(0.6 \mathrm{~g} \mathrm{~N} \mathrm{ha}^{-1}\right)$, but the increase of total protein content in the yield may have been caused by many micro-organisms present in the product. They mineralise organic matter and this way make nutrients more available to plants (Brussaard et al. 2007, Gyaneshwar et al. 2002, van Eekeren et al. 2010).

Total protein yield in dry matter of Dactylis glomerata L. was significantly larger, by about 13\%, than in Lolium perenne L., According to the literature (Maleux and Van den Ende 2007, Sosnowski et al. 2016), Dactylis glomerata L. is a plant rich in protein, which consequently results in its high yield. For both grass species the biggest yield of total protein was from plots where soil conditioners were applied together with mineral fertilisation. The yield of protein in Dactylis glomerata L. under the influence of the applied treatments increased two-fold, and in Lolium perenne L. by more than a half. However, the nitrogen content introduced to the soil together with soil conditioners is low. Therefore, it can be assumed that only a combination of mineral fertilisation and many micro-organisms present in soil conditioners had a significant impact on increasing the yield of total protein in dry matter of those grass species.

The average amount of total protein in Lolium perenne L. was not significantly different between years, and so, despite different hydro-thermal conditions, its content was at a similar level throughout the experiment. It can be assumed that soil conditioner application contributed to the stability of protein yield of that grass species. For each of the three soil conditioners, protein yield did not change significantly throughout the experiment, but it did in the case of mineral fertilisation applied on its own. 
Dactylis glomerata L., in the first two years of the research, produced yields at a stable level, with a significant decline in the third year, 2014. Such a significant reduction in the yield of protein in dry matter of Dactylis glomerata L. was caused by dynamically changing hydrothermal conditions during the growing period, indicating that this species is sensitive to adverse effects of the weather, and soil conditioners were no able to minimise this impact.

The application of Eko-Użyźniacz as well as UGmax, together with mineral fertilisation, resulted in a significantly higher yield of soluble carbohydrates, larger than on plots with other treatments. There was a significant difference between the yield of soluble sugars in dry matter of Lolium perenne L. and Dactylis glomerata L. According to the literature (Rawnsley et al. 2002, Moorby et al. 2006, Hammond et al. 2011, Hammond et al. 2013), Lolium perenne L. is a species known among other fodder grasses for its high content of simple sugars, which positively affects its palatability. Based on the results, it can be concluded that the use of UGmax with mineral fertilisation improved the yield of simple sugars in both species of grass. In consequence, this might have improved the taste of the forage from plots with the above treatment.

Examining the average annual yields of soluble carbohydrates throughout the experiment, it was found that the first year (2012) and the second one (2013) were characterised by significantly higher levels of nutrients produced by grass than the last year of the experiment (2014). According to the literature (Fulkerson and Donaghy 2001, Haigh 1995, Roche et al. 2009), the content of soluble carbohydrates in plants depends largely on the temperature, precipitation, and on the amount of sunshine. Adverse weather conditions in the last year of the experiment contributed to a significant reduction in the average yield of carbohydrates. Analysing the treatments in individual years of the research it was found that on plots where EkoUżyźniacz and Humus Active Papka were applied on their own or in combination with mineral fertilisation the amounts of simple sugars did not differ significantly.

\section{CONCLUSIONS}

1. Out of all treatments, UGmax with mineral fertilisation increased the yield of dry matter, total protein, and soluble carbohydrates to the highest degree.

2. Of the two species of grass, Dactylis glomerata L. produced the highest amounts of nutrients as a result of combined use of UGmax with mineral fertilisers (NPK), while the greatest dry matter and total protein yield of Lolium perenne L. came as a result of combined application of Eko-Użyźniacz with mineral fertilisation.

3. Comparing the species of grass, it turned out that plots with Dactylis glomerata L. had a larger dry matter and total protein yield, while those with Lolium perenne L. had more soluble carbohydrates. 
4. The soil conditioners applied in the experiment positively affected the content of the nutrients, which could have contributed to an increase in forage intake by animals. These results confirm the advantages of their use in farming, creating the possibility of a partial reduction of mineral fertiliser use.

\section{REFERENCES}

Bertilsson J., Akerlind M., Eriksson T., 2017. The effect of high-sugar ryegrass/red clover silage diets on intake, production, digestibility, and $\mathrm{N}$ utilization in dairy cows, as measured in vivo and predicted by the NorFor model. J. Dairy Sci., 100(10), 7990-8003, doi:10.3168/jds.2017-12874

Billman E.D., Goff B.M., Baldwin B.S., Prince K., Phillips T.D., 2017. Effects of vegetative coolseason grasses on forage removal by dairy heifers. Agron. J., 109(4), 1540-1550, doi: 10.2134/ agronj2016.10.0598

Brussaard L. de Ruiter P.C., Brown G.G., 2007. Soil biodiversity for agricultural sustainability. Agr. Ecosy. Environ., 121(3), 233-244, doi: 10.1016/j.agee.2006.12.013

Butkute B., Lemeziene N., Kanapeckas J., Navickas K., Dabkevicius Z., Venslauskas K., 2014. Cocksfoot, tall fescue and reed canary grass: Dry matter yield, chemical composition and biomass convertibility to methane. Biomass Bioenerg., 66, 1-11, doi: 10.1016/j.pbi.2008.03.002

Daly M.J., Stewart D.P.C., 1999. Influence of "effective microorganisms" (EM) on vegetable production and carbon mineralization - a preliminary investigation. J. Sustain. Agr., 14(2/3), 15-25, doi:10.1300/J064v14n02_04

Elsaesser M., Engel S., Breunig J., Thumm U., 2014. Increasing protein yields from grassland by reseeding of legumes. Grassland Sci. Eur., 19, 880-883.

Foito A., Byrne S.L., Shepherd T., Stewart D., Barth S., 2009. Transcriptional and metabolic profiles of Lolium perenne L. genotypes in response to a PEG-induced water stress. Plant Biotechnol. J., 7(8), 719-732, doi:10.1111/j.1467-7652.2009.00437.x

Fulkerson W.J., Donaghy D.J., 2001. Plant-soluble carbohydrate reserves and senescence - key criteria for developing an effective grazing management system for ryegrass-based pastures: a review. Aust. J. Exp. Agr., 41(2), 261-275, doi: 10.1071/EA00062

Gyaneshwar P., Naresh Kumar G., Parelih L.J., Poole P.S., 2002. Role of soil microorganisms in improving P nutrition of plant. Plant Soil, 245, 83-93, doi:10.1023/A:1020663916259

Haigh P.M., 1995. The composition of first-cut grass for ensilage in England and Wales from 1988 to 1991. Grass Forage Sci., 50(1), 63-67, doi: 10.1111/j.1365-2494.1995.tb02295.x

Hammond K.J., Burke J.L., Koolaard J.P., Muetzel S., Pinares-Patino C.S., Waghorn G.C., 2013. Effects of feed intake on enteric methane emission from sheep fed fresh white clover (Trifolium repens) and perennial ryegrass (Lolium perenne) forages. Anim. Feed Sci. Tech., 179, 1-4, 121-132.

Hammond K.J., Hoskin S.O., Burke J.L., Waghorn G.C., Koolaard J.P., Muetzel S., 2011. Effect of feeding fresh white clover (Trifolium repens) or perennial ryegrass (Lolium perenne) on enteric methane emission from sheep. Anim Feed Sci Tech, 166-167, 398-404, doi:10.1016/j. anifeedsci.2011.04.028

Huhtanen P., Broderick G., 2016. Improving utilisation of forage protein in ruminant production by crop and feed management. Grass Forage Sci. 61, 340-349.

Johansen M., Soegaard K., Weisbjerg M.R., 2016. Leaf/tem ratio as a tool to estimate field losses. Evaluation in dairy cows in early lactation. Grass Forage Sci., 61, 232-234.

Maleux K., Van den Ende W., 2007. Levans in excised leaves of Dactylis glomerata: Effects of light, sugars, temperature and senescence. J. Plant Biol., 50(6), 671-680, doi:10.1007/BF03030612 
Moorby M.J., Evans R.T., Scollan N.D., MacRae J.C., Theodorou M.K., 2006. Increased concentration of water-soluble carbohydrate in perennial ryegrass (Lolium perenne L.). Evaluation in dairy cows in early lactation. Grass Forage Sci., 61, 52-59, doi:10.1111/j.1365-2494.2006.00507.x

Peyraud J.L., Peeters A., 2016. The role of grassland based production system in the protein security. The multiple roles of grassland in the European bioeconomy. EGF. Grassland Sci. Eur., 21, 29-43.

Peyraud J.L., van den Pol-Van Dasselaar A., Collins R., Huguenin-Elie O., Dillon P., Peeters A., 2014. Multispecies swards and multi scale strategies for multifunctional grassland-base ruminant production system: an overview of the FP7-MultiSward Project. The Future of European Grasslands. EGF. Grassland Sci. Eur., 19, 695-715.

Rawnsley R.P., Donaghy D.J., Fulkerson W.J., Lane P.A., 2002. Changes in the physiology and feed quality of cocksfoot (Dactylis glomerata L.) during regrowth. Grass Forage Sci., 57(3), 2032011, doi:10.1046/j.1365-2494.2002.00318.x

Robins J.G., Bushman B.S., Feuerstein U., Blaser G., 2016. Variation and correlations among European and North American Orchardgrass germplasm for herbage yield and nutritive value. Agronomy-Basel 6(4), 61, doi: 10.3390/agronomy6040061

Roche J.R., Turner L.R., Lee J.M., Edmeades D.C., Donaghy D.J., Macdonald K.A., Penno J.W., Berry D.P., 2009. Weather, herbage quality and milk production in pastoral systems. 3. Interrelationships and associations between weather variables and herbage growth rate, quality and mineral concentration. Anim. Prod. Sci., 49(3), 211-221, doi: 10.1071/EA07309

Sanada Y., Tamura K., Yamada T., 2010. Relationship between water-soluble carbohydrates in fall and spring and vigor of spring regrowth in orchardgrass. Crop Sci., 50, 380-390, doi:10.2135/ cropsci2009.01.0031

Skowera B., Puła J., 2004. Pluviometric extreme conditions in spring season in Poland in the years 1971-2000. Acta Agroph. 3(1), 171-177

Sosnowski J., 2012. Reaction of Dactylis glomerata L., Festuca pratensis Huds. and Lolium perenne L. to microsoil conditioners fertilizer and mineral fertilization. Acta Sci. Pol., Agricultura, 11(1), 91-98.

Sosnowski J., Jankowski K., Domański P., 2016. Evolution of total protein content and the ratio of sugar-protein in dry matter of Dactylis glomerata and Festuca pratensis varieties depending on the type of soil. American J. Exp. Agric., 10(6), 1-8, doi: 10.9734/AJEA/2016/22110

Systematics of Polish soil. Annals of Soils Science, 62, 3, 2011.

Szczepanek M., Wilczewski E., 2011. Effect of humic substances on germination of wheat and barley under laboratory conditions. Acta Sci. Pol., Agricultura, 10(1), 79-86.

Tarakanovas P., Chomiak M., 2008. Evaluation of dry matter yield and its stability for cocksfoot varieties. Zemdiryste, 95(1), 153-161.

Tas B.M., Taweel H.Z., DMit H.J., ElgerDMa A., Dijkstra J., Tamminga S., 2006. Effects of perennial ryegrass cultivars on milk yield and nitrogen utilization in grazing dairy cows. J. Dairy Sci., 89, 3494-3500, doi:10.3168/jds.S0022-0302(06)72388-8

Van Eekeren N., Bos M., de Wit J., Keidel H., Bloem J., 2010. Effect of individual grass species and grass species mixtures on soil quality as related to root biomass and grass yield. Appl. Soil Ecol., 45(3), 275-283, doi: 10.1016/j.apsoil.2010.05.003

Vogel J., 2008. Unique aspects of the grass cell wall. Current Opinion in Plant Biology, 11(3), 301307, doi: 10.1016/j.pbi.2008.03.002 https://doi.org/10.1016/j.pbi.2008.03.002

Wilkins P.W., Humphreys M.O., 2003. Progress in breeding perennial grasses for temperate agriculture. J. Agr. Sci., 140(2), 129-150, doi: 10.1017/S0021859603003058 


\title{
WPŁYW PREPARATÓW BIOLOGICZNYCH NA PLON SUCHEJ MASY, BIAŁKA OGÓLNEGO ORAZ CUKRU DLA WYBRANYCH GATUNKÓW TRAW PASTEWNYCH
}

\author{
Kazimierz Jankowski, Milena Truba, Beata Wiśniewska-Kadżajan, Jacek Sosnowski, \\ Elżbieta Malinowska
}

\author{
Katedra Łąkarstwa i Kształtowania Terenów Zieleni, Wydział Przyrodniczy \\ Uniwersytet Przyrodniczo-Humanistyczny w Siedlcach \\ ul. Prusa 14, 08-110 Siedlce \\ e-mail: milena.truba@uph.edu.pl
}

\begin{abstract}
Streszczenie. Trzyletnie doświadczenie polowe założono jesienią 2011 roku na terenie obiektu doświadczalnego $\left(52^{\circ} 12^{\prime} \mathrm{N}, 22^{\circ} 28^{\prime} \mathrm{E}\right)$ należącego do Uniwersytetu Przyrodniczo-Humanistycznego w Siedlcach. Eksperyment założono w trzech powtórzeniach w układzie split-plot, a obiekt doświadczalny stanowiło poletko o powierzchni $3 \mathrm{~m}^{2}$. Celem badań było sprawdzenie czy dostępne na rynku preparaty biologiczne (UGmax, Eko-Użyźniacz, Humus Active Papka) stosowane w rolnictwie ekologicznym, w istotnym stopniu zwiększą parametry ilościowe paszy jakimi są plon suchej masy, plon białka ogólnego oraz plon węglowodanów rozpuszczalnych, na przykładzie wybranych gatunków traw pastewnych (Lolium perenne L., Dactylis glomerata L.). Spośród zastosowanych kombinacji nawozowych w najwyższym stopniu na poziom plonowania suchej masy paszy, białka ogólnego jak i węglowodanów rozpuszczalnych wpłynęło łączne stosowanie preparatu UGmax z nawożeniem mineralnym NPK. Zastosowane w badaniach biopreparaty glebowe pozytywnie wpływały na poziom plonowania testowanych parametrów, co mogło przyczynić się do wzrostu pobrania paszy przez zwierzęta. Wyniki te potwierdzają zasadność stosowania ich w rolnictwie ekologicznym, stwarzając jednocześnie możliwość częściowego ograniczenia nawożenia mineralnego.

Słowa kluczowe: preparaty biologiczne, plon suchej masy, plon białka, plon cukru, trawy, Dactylis glomerata L., Lolium perenne L.
\end{abstract}

